U.S. Geological Survey Water Availability and Use Science Program

\title{
Withdrawal and Consumption of Water by Thermoelectric Power Plants in the United States, 2015
}

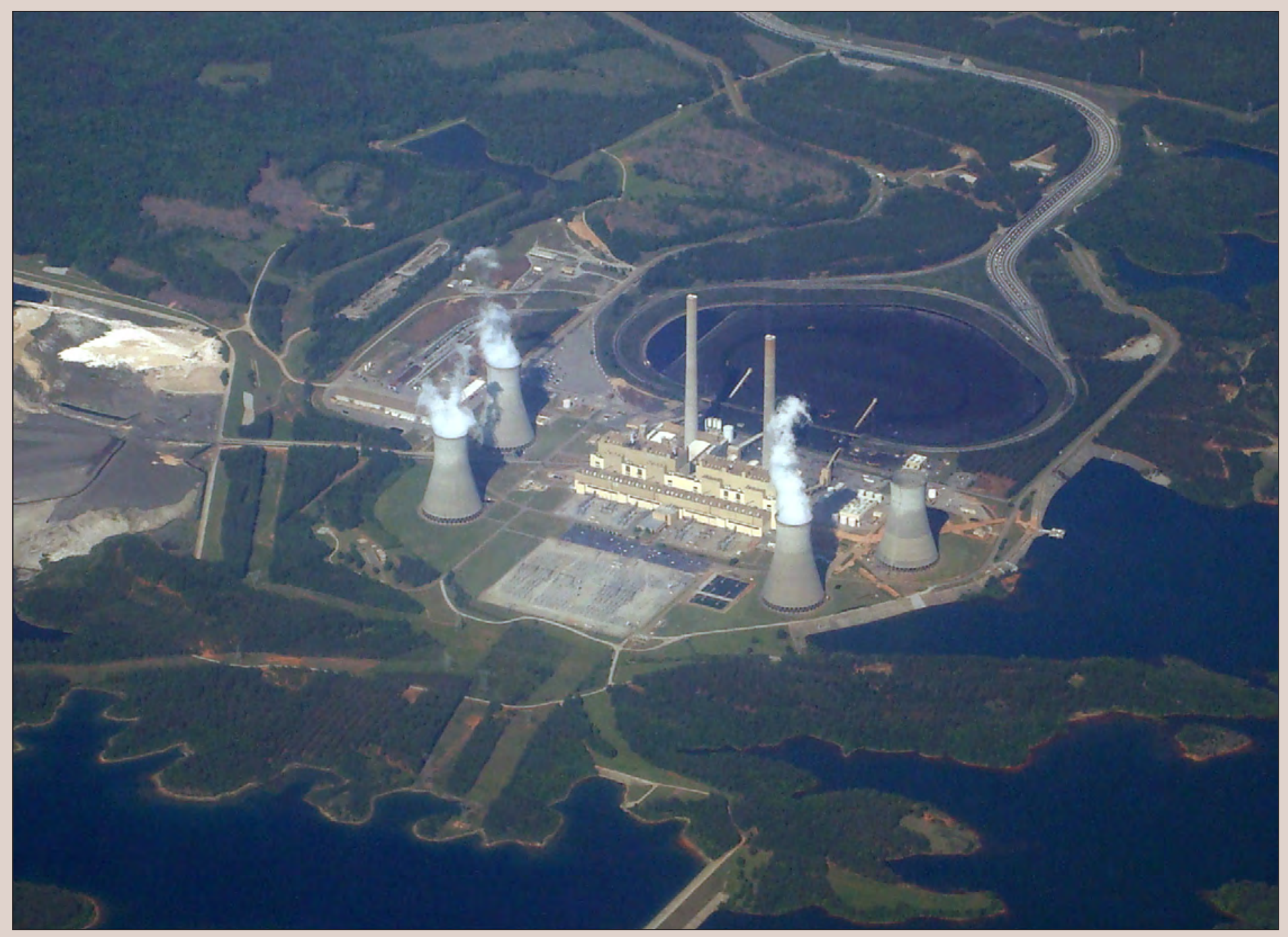

Scientific Investigations Report 2019-5103 
Cover. Aerial photograph of steam rising from the natural-draft cooling towers of the coal-fired Robert W Scherer Power Plant in Monroe County, Georgia, owned by Georgia Power Company. Photograph by Antennas [Public Domain], via Wikimedia Commons. 


\section{Withdrawal and Consumption of Water by Thermoelectric Power Plants in the United States, 2015}

By Melissa A. Harris and Timothy H. Diehl

U.S. Geological Survey Water Availability and Use Science Program

Scientific Investigations Report 2019-5103 


\title{
U.S. Department of the Interior DAVID BERNHARDT, Secretary
}

\author{
U.S. Geological Survey \\ James F. Reilly II, Director
}

U.S. Geological Survey, Reston, Virginia: 2019

For more information on the USGS - the Federal source for science about the Earth, its natural and living resources, natural hazards, and the environment-visit https://www.usgs.gov or call 1-888-ASK-USGS.

For an overview of USGS information products, including maps, imagery, and publications, visit https://store.usgs.gov.

Any use of trade, firm, or product names is for descriptive purposes only and does not imply endorsement by the U.S. Government.

Although this information product, for the most part, is in the public domain, it also may contain copyrighted materials as noted in the text. Permission to reproduce copyrighted items must be secured from the copyright owner.

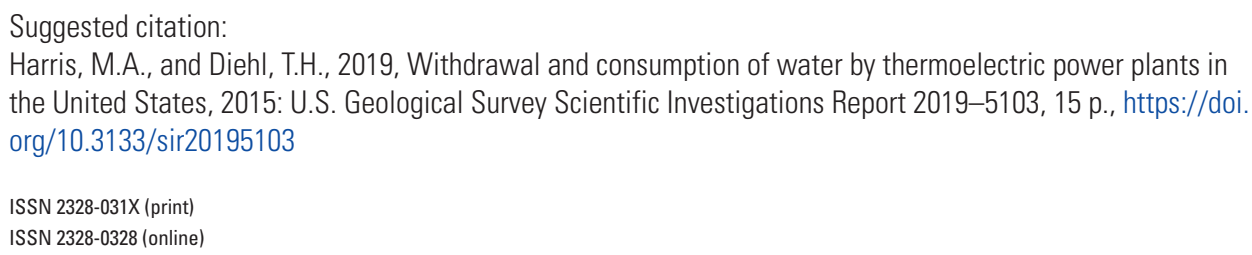




\section{Contents}

Abstract

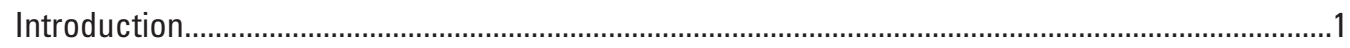

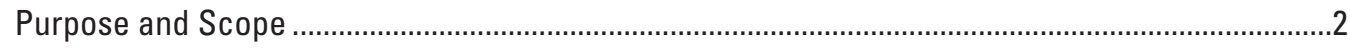

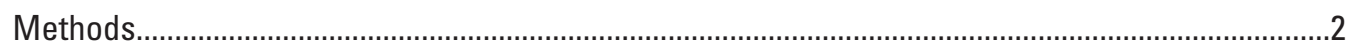

Differences Between Methods Used in 2010 and 2015 .......................................................

Development of Consumption and Withdrawal Coefficients ....................................................

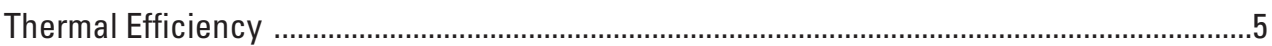

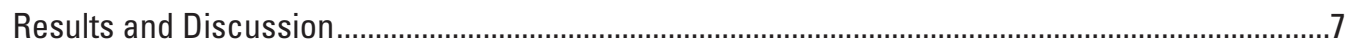

Model-Estimated Thermoelectric Water Use for 2015 ........................................................

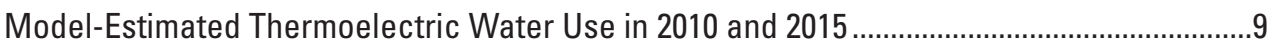

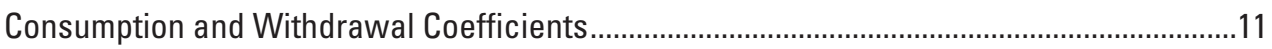

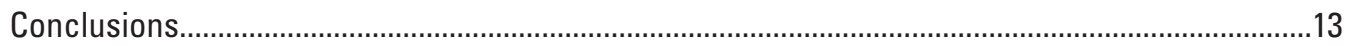



\section{Figures}

1. Map showing geographic distribution of 1,122 thermoelectric power plants modeled in $2015 .$.

2. Graph showing model-estimated withdrawals by cooling-system and generation technology type for thermoelectric power plants in the United States, 2010 and 2015 ......

3. Graph showing model-estimated consumption by cooling-system and generation technology type for thermoelectric power plants in the United States, 2010 and 2015 ...

4. Graph showing net electric generation by cooling-system and generation technology type for thermoelectric power plants in the United States, 2010 and 2015.

5. Graph showing consumption coefficients less than 1 gallon per kilowatthour by cooling-system technology type for 430 thermoelectric power plants in the United States, 2010 and 2015 .

6. Graph showing consumption coefficients by cooling-system technology type for 430 thermoelectric power plants in the United States, 2010 and 2015

7. Graph showing withdrawal coefficients by cooling-system type for 430 thermoelectric power plants in the United States, 2010 and 2015

\section{Tables}

1. Classification for condenser duty estimation method by generation technology type for thermoelectric power plants in the United States

2. Classification for modeling approach to consumption and withdrawal by coolingsystem technology type for thermoelectric power plants in the United States..

3. Net electrical generation for water-using, utility-scale thermoelectric power plants in the United States according to generation and cooling-system technology types as reported to the U.S. Energy Information Administration, and analyzed by the U.S. Geological Survey, 2010 and 2015.

4. Model-estimated water withdrawals by generation and cooling-system technology types for thermoelectric power plants in the United States, 2010 and 2015... 
5. Model-estimated water consumption by generation and cooling-system technology types for thermoelectric power plants in the United States, 2010 and 2015.

6. Withdrawal coefficients by generation and cooling-system technology types for thermoelectric power plants in the United States, 2010 and 2015

7. Consumption coefficients by generation and cooling-system technology types for thermoelectric power plants in the United States, 2010 and 2015

8. Average withdrawal coefficients by generation and cooling-system technology types for 430 thermoelectric power plants in the United States, 2010 and 2015.

9. Average consumption coefficients by generation and cooling-system technology types for 430 thermoelectric power plants in the United States, 2010 and 2015.

\section{Conversion Factors}

U.S. customary units to International System of Units

\begin{tabular}{|c|c|c|}
\hline Multiply & By & To obtain \\
\hline \multicolumn{3}{|c|}{ Length } \\
\hline mile (mi) & 1.609 & kilometer $(\mathrm{km})$ \\
\hline \multicolumn{3}{|c|}{ Volume } \\
\hline gallon (gal) & 3.785 & liter (L) \\
\hline gallon (gal) & 0.003785 & cubic meter $\left(\mathrm{m}^{3}\right)$ \\
\hline gallon (gal) & 3.785 & cubic decimeter $\left(\mathrm{dm}^{3}\right)$ \\
\hline million gallons (Mgal) & 3,785 & cubic meter $\left(\mathrm{m}^{3}\right)$ \\
\hline \multicolumn{3}{|c|}{ Rate } \\
\hline gallon per kilowatthour (gal/kWh) & $1.0515 \times 10^{-6}$ & liter per joule $(\mathrm{L} / \mathrm{J})$ \\
\hline million gallons per day (Mgal/d) & 0.04381 & cubic meter per second $\left(\mathrm{m}^{3} / \mathrm{s}\right)$ \\
\hline billion gallons per day (Bgal/d) & 43.813 & cubic meter per second $\left(\mathrm{m}^{3} / \mathrm{s}\right)$ \\
\hline \multicolumn{3}{|c|}{ Energy } \\
\hline kilowatthour (kWh) & $3,600,000$ & joule $(\mathrm{J})$ \\
\hline kilowatthour (kWh) & 3,412 & British thermal unit (Btu) \\
\hline megawatthour (MWh) & $3.6 \times 10^{9}$ & joule $(\mathrm{J})$ \\
\hline megawatthour (MWh) & $3.412 \times 10^{6}$ & British thermal unit (Btu) \\
\hline gigawatthour (GWh) & $3.412 \times 10^{9}$ & British thermal unit (Btu) \\
\hline
\end{tabular}

Temperature in degrees Celsius $\left({ }^{\circ} \mathrm{C}\right)$ may be converted to degrees Fahrenheit $\left({ }^{\circ} \mathrm{F}\right)$ as

$$
{ }^{\circ} \mathrm{F}=\left(1.8 \times{ }^{\circ} \mathrm{C}\right)+32 \text {. }
$$

\section{Datum}

Horizontal coordinate information is referenced to the North American Datum of 1983 (NAD 83).

\section{Abbreviations}

EBK empirical Bayesian kriging

EIA U.S. Energy Information Administration

MMBtu million British thermal units

NGCC natural gas combined cycle

USGS U.S. Geological Survey 


\title{
Withdrawal and Consumption of Water by Thermoelectric Power Plants in the United States, 2015
}

\author{
By Melissa A. Harris and Timothy H. Diehl
}

\section{Abstract}

The U.S. Geological Survey has developed models to estimate thermoelectric water use based on linked heat and water budgets. The models produced plant-level withdrawal and consumption estimates using consistent methods for 1,122 water-using, utility-scale thermoelectric power plants in the United States for 2015. Total estimated withdrawal for 2015 was about 103 billion gallons per day (Bgal/d), and total estimated consumption was about $2.7 \mathrm{Bgal} / \mathrm{d}$. Modelestimated withdrawals decreased approximately $26 \mathrm{Bgal} / \mathrm{d}$, or 20 percent, since 2010, and consumption decreased approximately 734 million gallons per day, or 21 percent. The decrease in thermoelectric water use between 2010 and 2015 can be attributed in part to a 7-percent decrease in total thermoelectric utility-scale electricity production, a combination of decreased electricity production and closure of coal-fired plants with once-through cooling systems, and the increase of electricity production at natural gas combinedcycle plants, which are more energy- and water-efficient than conventional thermoelectric plants.

\section{Introduction}

The thermoelectric power generation sector withdraws more water than any other category of water use (Maupin and others, 2014; Dieter and others, 2018), and the amount of water consumed can be substantial especially at smaller scales (such as county, river basin, or aquifer) (Dieter and others, 2018; Lee and others, 2018). Historically, thermoelectric water-use data from Federal surveys and compilations have been inconsistent and incomplete (Averyt and others, 2013; Diehl and Harris, 2014; Peer and Sanders, 2016), and estimates disagree due in part to differences in various data sources comprising the datasets and methodologies to estimate water use (Harris and Diehl, 2017). Furthermore, thermoelectric water-use estimates and coefficients span a wide range of values for similar generation and coolingsystem technologies (Macknick and others, 2011; Meldrum and others, 2013).
Federally reported thermoelectric water withdrawal totals have decreased since 2005 in part because of the retirement of plants with once-through cooling systems, conversion of oncethrough cooling systems to recirculating cooling systems, environmental regulations constraining once-through cooling systems, and more natural gas combined-cycle (NGCC) plants coming online (Maupin and others, 2014; Dieter and others, 2018). The use of natural gas at combined-cycle plants using recirculating or dry-cooling systems and at gas-combustion turbines that do not use water has increased because of the low cost and availability of natural gas (U.S. Energy Information Administration, 2016a, b; Arias and others, 2017). Conversely, the use of coal has declined, including reduced operations and closures of many coal-fired thermoelectric plants with withdrawal-intensive once-through cooling systems (U.S. Energy Information Administration, 2016a; Arias and others, 2017; Kolstad, 2017). From 2008 through 2017, 47 percent of the total retired generation capacity was from coal-fired power plants (U.S. Energy Information Administration, 2018). Furthermore, Section 316(b) of the Clean Water Act requires facilities with cooling intake structures to reduce intake flows to levels commensurate with recirculating systems to minimize the impingement (being pinned against intake structures) and entrainment (being drawn into cooling systems) of aquatic organisms (U.S. Environmental Protection Agency, 2014). This new regulation imposes costly upgrades for plants with once-through cooling systems, thus motivating the replacement of those systems with recirculating cooling towers or dry-cooling towers (Electric Power Research Institute, 2012) or shutting the plant down. The increased use of recirculating cooling systems could increase national total thermoelectric water consumption, but a decrease is possible as well because of the opening of new NGCC plants, which are more water-efficient than other types of thermoelectric plants.

U.S. Geological Survey (USGS) models provide a consistent method for estimating water use across the different types of water-using, utility-scale thermoelectric plants in the United States (Diehl and others, 2013; Diehl and Harris, 2014) and a quality-assurance check of federally reported data (Harris and Diehl, 2017). The estimates presented in this report mark the second set of thermodynamically based model estimates completed, the other being for 2010 (Diehl 
and Harris, 2014). The water-use estimates from 2010 and 2015 are derived from the same methodology, thus allowing comparison of the estimates from the two time periods.

\section{Purpose and Scope}

This report presents USGS model-estimated withdrawal and consumption rates for 1,122 water-using, utility-scale thermoelectric power plants in the United States, excluding Puerto Rico and the U.S. Virgin Islands, for 2015 (fig. 1). These plants generated approximately 82 percent of all electricity produced by utility-scale power producers in the United States in 2015. This report also provides a brief trend analysis (2010-2015) of USGS model-estimated thermoelectric water use. Data associated with this study are publicly available from Harris and Diehl (2019).

\section{Methods}

The USGS thermoelectric water-use models are based on linked heat and water budgets. The budgets are determined by a power plant's generation and cooling-system technologies, fuel heat, electricity generation, and environmental variables including wet- and dry-bulb air temperature, water temperature, wind speed, and elevation. Because plant technologies dictate the flow of heat and water through a facility, plants were categorized according to their generation and cooling-system technology types for model calculations (Diehl and others, 2013). The amount of heat used to generate electricity is determined by a plant's generation technology, which encompasses its energy source and prime mover (table 1). Thermoelectric prime movers, the turbines that convert thermal energy in heated gases to mechanical energy, include combustion-steam turbines and combined-cycle turbines. Combustion-steam turbines can be powered by many energy sources, but most fit under the broad fuel categories of coal, oil, gas, and biomass. Combined-cycle plants, a combination of gas-combustion and combustion-steam turbines, are overwhelmingly powered by natural gas and were therefore categorized as NGCC plants. Nuclear power plants, which have thermal-steam turbines but share the "steam-driven" prime mover identification with combustion-steam turbines, were categorized according to their energy source. Plants with more than one type of prime mover and those that used multiple fuel sources (no one fuel was used for 90 percent of fuel heat) were categorized as complex generation. A plant's condenser duty, the amount of waste heat transferred to the cooling system in the condenser, was estimated by using heat budgets developed for each generation technology type (Diehl and others, 2013; table 1).
The amount of water that is withdrawn and consumed by a plant is determined primarily by its cooling-system technology. Cooling-system technology types were broadly categorized as once-through cooling systems and recirculating cooling systems (table 2). Once-through cooling systems withdraw relatively large volumes of water (relative to power generated and the lesser amount of water withdrawn for recirculating systems), direct the water through the plant's condenser to cool the steam used to turn the turbines and generate electricity, and then discharge the water at a higher temperature to a surface-water body. Consumption for a once-through system is represented by the forced evaporation from the surface-water body that receives the heated discharge water (Diehl and others, 2013). Withdrawal for a once-through system is based on the plant's condenser duty and condenser range, or the increase in cooling-water temperature as it passes through the condenser (Diehl and Harris, 2014). Once-through systems were further classified according to the type of water body upon which they rely: freshwater sources such as rivers, lakes, and ponds or saline-water sources such as oceans, bays, and estuaries (table 2).

Recirculating cooling systems withdraw much less water than once-through systems because they route the water through the plant's condenser and then recirculate the water between the cooling system and the condenser. Recirculating cooling systems were further classified into recirculating towers and recirculating ponds or lakes (table 2). The consumption rate at recirculating systems is higher than at once-through systems and represents evaporation from towers or from the surface of ponds or lakes (Diehl and others, 2013). The withdrawal for recirculating systems is the amount of water withdrawn to compensate, or make up, for losses from the systems, including consumption and blowdown (Diehl and Harris, 2014).

Some plants have more than one type of cooling system, in which case they were categorized as complex (table 2). Water use was estimated as the sum of withdrawal and consumption for each type of cooling system (Diehl and others, 2013; Diehl and Harris, 2014). The most common configuration of a complex-cooled plant is a once-through cooling system with recirculating towers. Plants with either complex cooling or complex generation were considered "complex plants," and plants with a single type of prime mover, a single dominant fuel, and a single type of cooling system were classified as "simple plants."

It is important to note that the thermoelectric water-use models estimate the amount of water necessary to condense the steam used to generate electricity, and not the amount of water that is withdrawn when a plant is not generating electricity. Approximately 32 percent of all thermoelectric water withdrawals occur when no electricity is being generated, and this occurs mostly at peaking and intermediate plants to maintain dispatchability (Clement and others, 2017). 


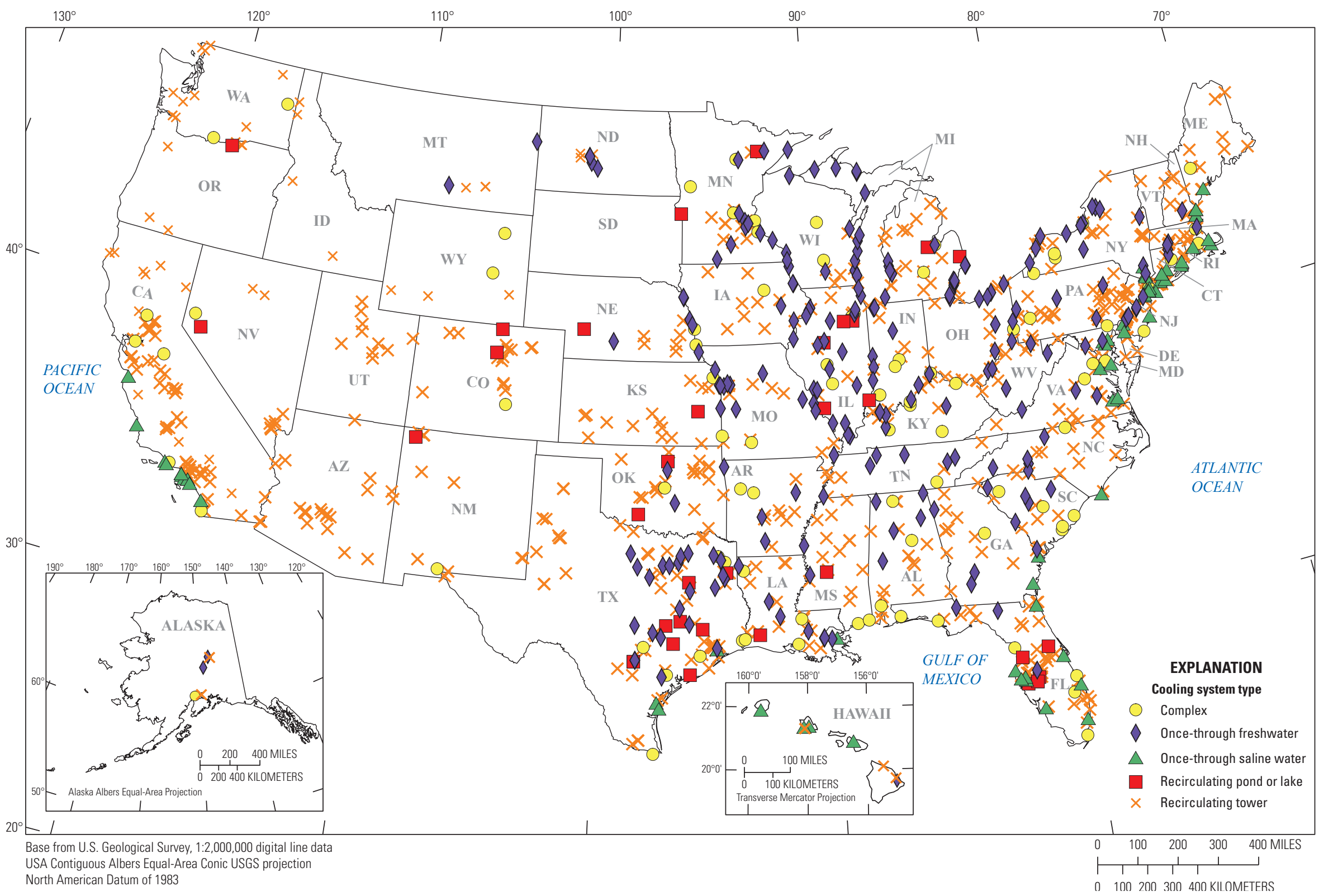

Figure 1. Geographic distribution of 1,122 thermoelectric power plants modeled in 2015. [Thermoelectric plants in Puerto Rico and the U.S. Virgin Islands are not surveyed by the U.S. Energy Information Administration.] 
Table 1. Classification for condenser duty estimation method by generation technology type for thermoelectric power plants in the United States (modified from Diehl and Harris, 2014).

\begin{tabular}{lll}
\hline \multicolumn{1}{c}{ Generation technology type } & \multicolumn{1}{c}{ Prime mover } & Energy source \\
\hline Biomass & Combustion steam & Biomass \\
Coal & Combustion steam & Coal \\
Gas steam & Combustion steam & Natural gas \\
& Combined-cycle combustion part & \\
Natural gas combined cycle (NGCC) ${ }^{*}$ & Combined-cycle steam part & Various sources, dominated by natural gas \\
& Combined-cycle single shaft & \\
Nuclear & Thermal steam & Nuclear \\
Oil & Combustion steam & Oil \\
Complex & Multiple & Various sources \\
\hline
\end{tabular}

"Four combined-cycle plants that use oil as a fuel source are included in the NGCC category for recirculating towers in 2015.

Table 2. Classification for modeling approach to consumption and withdrawal by cooling-system technology type for thermoelectric power plants in the United States (modified from Diehl and Harris, 2014).

\begin{tabular}{lll}
\hline \multicolumn{1}{c}{$\begin{array}{c}\text { Cooling-system } \\
\text { technology type }\end{array}$} & \multicolumn{1}{c}{ Consumption modeling approach } & Withdrawal modeling approach \\
\hline Once-through freshwater & Water surface evaporation model & Based on condenser duty and range \\
\hline $\begin{array}{l}\text { Once-through saline water } \\
\text { Recirculating pond or lake }\end{array}$ & $\begin{array}{l}\text { Not modeled } \\
\text { Water surface evaporation model and Penman-Mon- } \\
\text { teith model }\end{array}$ & $\begin{array}{l}\text { Equal to consumption } \\
\text { Recirculating tower }\end{array}$ \\
Complex & Wet tower evaporation model & Ratio to consumption \\
\hline
\end{tabular}

\section{Differences Between Methods Used in 2010 and 2015}

Data sources and methods for obtaining environmental variables for the consumption and withdrawal models are the same as those of Diehl and others (2013), with the exception of water-temperature determination. For the 2015 estimates, the National Oceanic and Atmospheric Administration's Great Lakes Environmental Research Laboratory's Great Lakes Surface Environmental Analysis (National Oceanic and Atmospheric Administration, 2015) was excluded because it did not provide for better estimates than empirical Bayesian kriging (EBK; Pilz and Spöck, 2007; Krivoruchko, 2012; Diehl and others, 2013). Additionally, code was written using the R-environment to pull water-temperature data stored in the USGS National Water Information System (R Development Core Team, 2017; U.S. Geological Survey, 2017). For 2015, there were 1,328 USGS streamgages with monthly water-temperature data (in degrees Celsius) based on daily averages (75 percent or greater daily values per month), 864 of which had 12 months of data. The U.S. Energy Information Administration (EIA)-reported intake water-temperature data were used for once-through plants where temperature was measured. There was no deviation from the methods of Diehl and others (2013) for the EIA-reported water-temperature data. Quality-control checks flagged 305 sites (USGS streamgages and EIA plants) that had daily water temperatures greater than three standard deviations from the monthly mean; these sites were excluded from the EBK analysis.

Geothermal and solar thermal plants were excluded in the 2015 estimates because available data are insufficient to characterize their heat and water budgets. The heat and water budget models are dependent on the thermal efficiency of the heat engine - the amount of heat transferred to steam, or, in gas-combustion turbines, directly to electric generation - relative to the total amount of heat produced in the plant. Unlike combustion-steam, nuclear, and NGCC plants, geothermal plants use a thermal resource that is highly variable in temperature, which affects plant efficiency (Zarrouk and Moon, 2014). Additionally, geothermal plants differ in plant design. Some geothermal plants use working fluids other than steam (Taylor and Krumdieck, 2013; Astolfi and others, 2014; Tchanche, 2016). Moreover, some geothermal resources are "dry," while some consist of steam vented from geologic formations. Where steam is part of the resource, it is generally condensed, and the plant produces water rather than withdrawing and consuming water. As a result of variability in temperature and steam content of the resource and in the range of designs, there is not enough information to develop reliable estimates of condenser duty (waste heat) at all geothermal 
plants. Solar thermal plants have similar issues to geothermal plants. The amount of solar energy collected and transferred to the working fluid is variable relative to the capacity of the plant; most plants are in areas of scarce water, and water use is variable across such plants (Carter and Campbell, 2009; Damerau and others, 2011; Bracken and others, 2015). Several solar-thermal plants are essentially gas-steam plants with a solar boost. As a result of the unknown degree of variability in heat budgets for geothermal, solar thermal, and integrated gasification combined-cycle plants (Stiegel and others, 2005) and the lack of plant-specific data to characterize their unique heat budgets, the type of heat and water budget models used for more common plant types cannot be applied with confidence in their results.

For 2015, there were 55 geothermal and solar thermal plants that reported plant data to the EIA. They represented less than 1 percent of net thermoelectric power generated by electric utilities and independent power producers (plants associated with industrial and commercial facilities are outside the scope of this paper) (U.S. Energy Information Administration, 2016c, d). Of the 55 plants that generated electricity in 2015, 48 were modeled in 2010 with an estimated 82 million gallons per day (Mgal/d) of water withdrawals and $58 \mathrm{Mgal} / \mathrm{d}$ of water consumption, 0.06 percent and 1.66 percent of 2010 model-estimated withdrawal and consumption, respectively. These plants represented less than 1 percent of 2010 net thermoelectric power generation of the modeled plants (U.S. Energy Information Administration, 2011), and they were removed from the 2010 data analysis for this report.

\section{Development of Consumption and Withdrawal Coefficients}

Plants that have multiple cooling-system technology types, generation technology types, and (or) use multiple fuels present challenges in allocating water use to distinct generation types and were not included in the evaluation of categorical coefficients. These "complex plants" represent about 18 percent and 14 percent of net generation in 2010 and 2015 , respectively, for all plants considered in this analysis (table 3).

Consumption and withdrawal coefficients in gallons per kilowatthour were estimated for 889 simple plants in 2010 and 958 simple plants in 2015. Coefficients were estimated as the ratio of total annual consumption or withdrawal to annual net generation across all plants with each combination of generation and cooling-system technology types. Uncertainty in model predictions associated with high and low estimated threshold values for consumption and withdrawal at each plant is not reflected in these coefficients.

The plants included in each category changed from 2010 to 2015 through creation of new generation categories, new plant construction, retirements, and modifications to plants. At plants that export heat, the proportion of exported heat changes from year to year. These and other changes alter thermal efficiency from year to year.

To examine differences in coefficients not associated with such changes, categorical coefficients were calculated for a subset of 430 simple plants that belonged to the same generation and cooling categories in 2010 and 2015. In this subset, exported heat did not exceed 5 percent of fuel heat in either year, and the change in thermal efficiency from 2010 to 2015 did not exceed 10 percent of the smaller of the two values.

\section{Thermal Efficiency}

For any boiler-generator association in any month, thermal efficiency is calculated as the ratio of the net generation energy divided by the energy consumed in the fuel, as reported to the EIA. The thermal efficiency of thermoelectric generation is variable; efficiency is higher in combined-cycle plants and large, new steam plants, and efficiency is lower in old, small steam plants, plants that burn waste materials, and combined-heat-and-power plants. Still, values of thermal efficiency can be too high or too low to be plausible, indicating data that will produce poor estimates of condenser duty and water use.

Some plants report monthly fuel consumption, but little, no, or negative net electric generation, thus implying low or zero thermal efficiency. Many of these monthly values, particularly negative net generation, indicate months in which the primary use of the boiler-generator association was as spinning reserve (burning fuel to keep the turbine spinning to quickly respond to demand). At least 1 month with negative net generation was reported at 249 plants (U.S. Energy Information Administration, 2016d). However, some instances of fuel consumption without positive net generation do not fit this pattern.

Some months have more net generation relative to fuel consumption than can plausibly be produced. For NGCC plants, 58 percent thermal efficiency was considered the maximum plausible value (Rao, 2012), while for steam plants, 44 percent was the maximum plausible value (Storm, 2018). Higher efficiencies than these are theoretically possible under ideal conditions but not consistently achieved as monthly averages by existing plants, and when reported, they indicate data problems.

Of 1,061 nonnuclear plants modeled, 271 were affected by issues of unrealistic thermal efficiency (U.S. Energy Information Administration, 2016d). Fifty-seven plants had months with implausibly high thermal efficiency, including 12 plants with months in which net generation was reported but fuel heat was unreported or zero. Months in which fuel was burned but net generation was zero or negative were reported by 241 plants.

To evaluate how much condenser duty might be affected by months with implausible efficiency, condenser duty was removed, or "masked," for such months. This reduced total 
Table 3. Net electrical generation for water-using, utility-scale thermoelectric power plants in the United States according to generation and cooling-system technology types as reported to the U.S. Energy Information Administration (2011, 2016b), and analyzed by the U.S. Geological Survey (USGS), 2010 and 2015.

[All values are in gigawatthours. Data for 2010 are based on 1,242 plants. Data for 2015 are based on 1,122 plants. Values may not sum to totals because of independent rounding. NGCC, natural gas combined cycle; n/a, not applicable

\begin{tabular}{|c|c|c|c|c|c|c|c|c|c|c|c|c|}
\hline \multirow{3}{*}{$\begin{array}{c}\text { Generation } \\
\text { technology } \\
\text { type }\end{array}$} & \multicolumn{10}{|c|}{ Cooling-system technology type } & & \\
\hline & \multicolumn{2}{|c|}{$\begin{array}{c}\text { Once-through } \\
\text { freshwater }\end{array}$} & \multicolumn{2}{|c|}{$\begin{array}{l}\text { Once-through } \\
\text { saline water }\end{array}$} & \multicolumn{2}{|c|}{$\begin{array}{l}\text { Recirculating } \\
\text { pond or lake }\end{array}$} & \multicolumn{2}{|c|}{$\begin{array}{c}\text { Recirculating } \\
\text { tower }\end{array}$} & \multicolumn{2}{|c|}{ Complex } & \multicolumn{2}{|c|}{ Totals } \\
\hline & 2010 & 2015 & 2010 & 2015 & 2010 & 2015 & 2010 & 2015 & 2010 & 2015 & 2010 & 2015 \\
\hline Biomass & $\mathrm{n} / \mathrm{a}$ & 2,511 & $\mathrm{n} / \mathrm{a}$ & 499 & $\mathrm{n} / \mathrm{a}$ & 296 & $\mathrm{n} / \mathrm{a}$ & 19,840 & $\mathrm{n} / \mathrm{a}$ & 832 & $\mathrm{n} / \mathrm{a}$ & 23,976 \\
\hline Coal & 558,754 & 368,007 & 26,854 & 12,782 & 104,311 & 79,355 & 731,552 & 606,860 & 324,495 & 193,543 & $1,745,966$ & $1,260,547$ \\
\hline Complex & 32,974 & 47,042 & 37,165 & 16,156 & 10,686 & 9,812 & 64,402 & 32,412 & 124,872 & 96,067 & 270,100 & 201,488 \\
\hline Gas steam & 22,473 & 11,450 & 12,190 & 21,387 & 3,484 & 3,193 & 14,231 & 13,773 & 7,304 & 8,432 & 59,682 & 58,234 \\
\hline NGCC* & 12,219 & 23,420 & 30,773 & 50,824 & 16,707 & 44,444 & 492,128 & 758,340 & 31,326 & 9,379 & 583,152 & 886,407 \\
\hline Nuclear & 144,978 & 149,357 & 160,038 & 147,466 & 77,502 & 66,427 & 272,506 & 277,785 & 137,046 & 137,373 & 792,069 & 778,408 \\
\hline Oil & 137 & 74 & 5,091 & 4,531 & $\mathrm{n} / \mathrm{a}$ & $\mathrm{n} / \mathrm{a}$ & 413 & 187 & $\mathrm{n} / \mathrm{a}$ & 423 & 5,641 & 5,215 \\
\hline Totals & 771,535 & 601,860 & 272,111 & 253,645 & 212,689 & 203,526 & $1,575,232$ & $1,709,196$ & 625,043 & 446,048 & $3,456,609$ & $3,214,275$ \\
\hline
\end{tabular}

"Four combined-cycle plants that use oil as a fuel source are included in the NGCC category for recirculating towers in 2015. 
condenser duty at all plants by 20 million British thermal units (MMBtu) out of a total of 11 billion Btu-about 0.2 percent of all condenser duty. This net result combines increases in duty at some plants of 33 MMBtu with decreases of 13 MMBtu at other plants. For 28 plants, deleting implausible condenser duty for those months (in other words, "masking") altered estimated condenser duty by more than 5 percent. Though the majority of plants with implausible thermal efficiency had negative net generation at some units (suggesting use for spinning reserve), only 10 of these 28 were such plants. An attempt was made to develop a way to reconstruct actual fuel use and net generation at these 28 plants, but the apparent type of error that produced implausible thermal efficiency varied among them and did not produce a convincing result.

Estimated condenser duty could be revised for 6 of the previously mentioned 28 plants that accounted for 7 MMBtu of changes in duty resulting from masking implausible months. At two plants (plants 976 and 3797, see Harris and Diehl, 2019), combining multiple boiler-generator associations into one association resolved the misallocation of fuel or net generation. Fuel heat was reallocated from one boilergenerator association to another at plant 126, whereas net generation was reapportioned between two boiler-generator associations at plant 3287. For plant 564, net generation was not reported for 1 month; therefore, net generation for that month was estimated based on fuel use and the efficiency of the plant in other months. Similarly, at plant 3457, fuel use was not reported for 1 month, so fuel use for that month was estimated based on net generation and average efficiency.

Examination of the other 22 plants with more than 5-percent alteration of estimated condenser duty suggested that attempts to improve estimates would generally require ad hoc methods based on circumstantial evidence, as at these 6 plants. Examining thermal efficiency can identify plants with problematic data, but it does not lead to a consistent method for correcting estimated condenser duty. This is a limitation of the modeling approach, but at most plants, the consequences of problematic data produce less error than other sources of error. The overall amount of error is small relative to total condenser duty.

Ultimately, corrected estimates of condenser duty were used at six plants, and corrections were not made at other plants. The 28 plants with at least 5 percent of their condenser duty affected by concerns of implausible thermal efficiency were not used in calculating water-use coefficients.

\section{Results and Discussion}

Model-based plant-specific estimates of thermoelectric water withdrawal and consumption for 2015 were the primary results of this study (Harris and Diehl, 2019). These estimates and the coefficients of withdrawal and consumption developed from them were aggregated by plant category and compared to estimates and coefficients for 2010 .

\section{Model-Estimated Thermoelectric Water Use for 2015}

Total national-level model-estimated water withdrawal was approximately 103 billion gallons per day (Bgal/d) for 1,122 water-using, utility-scale thermoelectric power plants in the United States in 2015 (table 4). Plants with once-through cooling systems withdrew the greatest amounts of water, accounting for 76 percent of all withdrawals. Once-through freshwater systems withdrew about $55 \mathrm{Bgal} / \mathrm{d}$, and oncethrough saline-water systems withdrew about $23 \mathrm{Bgal} / \mathrm{d}$. Plants with recirculating cooling systems withdrew approximately $2.4 \mathrm{Bgal} / \mathrm{d}$, with 90 percent of that water withdrawn by plants with recirculating cooling towers. Plants with complex cooling systems, the most common configuration being a once-through system and recirculating towers, withdrew approximately $23 \mathrm{Bgal} / \mathrm{d}$ of water, or 22 percent of total withdrawals.

Total national-level model-estimated water consumption was approximately $2.7 \mathrm{Bgal} / \mathrm{d}$, which was about 3 percent of the total water withdrawn (table 5). Plants with freshwater, once-through cooling systems consumed approximately $566 \mathrm{Mgal} / \mathrm{d}$, or less than 1 percent of total withdrawals and 21 percent of total consumption. Plants with recirculating cooling systems consumed 74 percent of the water they withdrew $(1.7 \mathrm{Bgal} / \mathrm{d})$, representing 64 percent of total consumption. Plants with complex cooling systems consumed $422 \mathrm{Mgal} / \mathrm{d}$, or 15 percent of total consumption.

The plants in this study produced 3,214,275 gigawatthours (GWh) of electricity, which was 82 percent of the electricity generated by electric utilities and independent power producers in the United States in 2015 (table 3). Plants with recirculating towers generated the greatest share of electricity, with about $1,709,000 \mathrm{GWh}$, or 53 percent of total net electricity generation. Of the electricity generated by recirculating tower plants, 44 percent of the electricity was generated by NGCC plants, followed by coal-fired plants (36 percent) and nuclear plants (16 percent).

Plants with once-through cooling systems generated 27 percent of total net electrical generation, and plants with complex cooling systems and recirculating ponds generated 14 and 6 percent of total net generation, respectively (table 3 ). Coal-fired plants, regardless of cooling-system type, generated 39 percent of electricity, followed by NGCC (28 percent), nuclear (24 percent), complex (multifuel) (6 percent), gassteam ( 2 percent), biomass ( 0.7 percent), and oil-fired plants (0.2 percent). 
Table 4. Model-estimated water withdrawals by generation and cooling-system technology types for thermoelectric power plants in the United States, 2010 and 2015.

[All values are in million gallons per day. Estimates for 2010 are based on 1,242 plants. Estimates for 2015 are based on 1,122 plants. Values may not sum to totals because of independent rounding. NGCC, natural gas combined cycle; $\mathrm{n} / \mathrm{a}$, not applicable]

\begin{tabular}{|c|c|c|c|c|c|c|c|c|c|c|c|c|}
\hline \multirow{3}{*}{$\begin{array}{c}\text { Generation } \\
\text { technology } \\
\text { type }\end{array}$} & \multicolumn{10}{|c|}{ Cooling-system technology type } & & \\
\hline & \multicolumn{2}{|c|}{$\begin{array}{l}\text { Once-through } \\
\text { freshwater }\end{array}$} & \multicolumn{2}{|c|}{$\begin{array}{l}\text { Once-through } \\
\text { saline water }\end{array}$} & \multicolumn{2}{|c|}{$\begin{array}{l}\text { Recirculating } \\
\text { pond or lake }\end{array}$} & \multicolumn{2}{|c|}{$\begin{array}{l}\text { Recirculating } \\
\text { tower }\end{array}$} & \multicolumn{2}{|c|}{ Complex } & \multicolumn{2}{|c|}{ Totals } \\
\hline & 2010 & 2015 & 2010 & 2015 & 2010 & 2015 & 2010 & 2015 & 2010 & 2015 & 2010 & 2015 \\
\hline Biomass & $\mathrm{n} / \mathrm{a}$ & 448 & $\mathrm{n} / \mathrm{a}$ & 87 & $\mathrm{n} / \mathrm{a}$ & 1 & $\mathrm{n} / \mathrm{a}$ & 53 & $\mathrm{n} / \mathrm{a}$ & 1 & $\mathrm{n} / \mathrm{a}$ & 590 \\
\hline Coal & 49,489 & 32,720 & 2,363 & 1,210 & 187 & 107 & 1,273 & 940 & 13,631 & 7,912 & 66,943 & 42,889 \\
\hline Complex & 3,221 & 3,804 & 2,733 & 1,135 & 25 & 2 & 140 & 52 & 4,856 & 2,326 & 10,975 & 7,319 \\
\hline Gas steam & 2,420 & 1,059 & 1,261 & 2,120 & 21 & 7 & 32 & 26 & 383 & 544 & 4,116 & 3,756 \\
\hline $\mathrm{NGCC}^{*}$ & 446 & 916 & 1,213 & 1,884 & 16 & 20 & 386 & 515 & 151 & 28 & 2,212 & 3,362 \\
\hline Nuclear & 15,405 & 15,954 & 17,019 & 15,739 & 166 & 87 & 608 & 530 & 10,524 & 11,825 & 43,723 & 44,135 \\
\hline Oil & 21 & 8 & 659 & 445 & 0 & 0 & 1 & 0 & 0 & 44 & 681 & 497 \\
\hline Totals & 71,002 & 54,908 & 25,247 & 22,620 & 415 & 237 & 2,441 & 2,117 & 29,545 & 22,680 & 128,650 & 102,549 \\
\hline
\end{tabular}

"Four combined-cycle plants that use oil as a fuel source are included in the NGCC category for recirculating towers in 2015.

Table 5. Model-estimated water consumption by generation and cooling-system technology types for thermoelectric power plants in the United States, 2010 and 2015.

[All values are in million gallons per day. Estimates for 2010 are based on 1,156 plants. Estimates for 2015 are based on 1,052 plants. Values may not sum to totals because of independent rounding. NGCC, natural gas combined cycle; $\mathrm{n} / \mathrm{a}$, not applicable]

\begin{tabular}{|c|c|c|c|c|c|c|c|c|c|c|c|c|}
\hline \multirow{3}{*}{$\begin{array}{c}\text { Generation } \\
\text { technology } \\
\text { type }\end{array}$} & \multicolumn{10}{|c|}{ Cooling-system technology type } & & \\
\hline & \multicolumn{2}{|c|}{$\begin{array}{l}\text { Once-through } \\
\text { freshwater }\end{array}$} & \multicolumn{2}{|c|}{$\begin{array}{l}\text { Once-through } \\
\text { saline water }\end{array}$} & \multicolumn{2}{|c|}{$\begin{array}{l}\text { Recirculating } \\
\text { pond or lake }\end{array}$} & \multicolumn{2}{|c|}{$\begin{array}{l}\text { Recirculating } \\
\text { tower }\end{array}$} & \multicolumn{2}{|c|}{ Complex } & \multicolumn{2}{|c|}{ Totals } \\
\hline & 2010 & 2015 & 2010 & 2015 & 2010 & 2015 & 2010 & 2015 & 2010 & 2015 & 2010 & 2015 \\
\hline Biomass & $\mathrm{n} / \mathrm{a}$ & 4 & $\mathrm{n} / \mathrm{a}$ & $\mathrm{n} / \mathrm{a}$ & $\mathrm{n} / \mathrm{a}$ & 1 & $\mathrm{n} / \mathrm{a}$ & 38 & $\mathrm{n} / \mathrm{a}$ & 1 & $\mathrm{n} / \mathrm{a}$ & 44 \\
\hline Coal & 503 & 335 & $\mathrm{n} / \mathrm{a}$ & $\mathrm{n} / \mathrm{a}$ & 187 & 107 & 877 & 671 & 340 & 197 & 1,907 & 1,310 \\
\hline Complex & 33 & 39 & $\mathrm{n} / \mathrm{a}$ & $\mathrm{n} / \mathrm{a}$ & 25 & 2 & 100 & 37 & 83 & 49 & 241 & 128 \\
\hline Gas steam & 27 & 12 & $\mathrm{n} / \mathrm{a}$ & $\mathrm{n} / \mathrm{a}$ & 21 & 7 & 23 & 19 & 8 & 5 & 79 & 43 \\
\hline $\mathrm{NGCC}^{2}$ & 5 & 9 & $\mathrm{n} / \mathrm{a}$ & $\mathrm{n} / \mathrm{a}$ & 16 & 20 & 269 & 368 & 12 & 3 & 302 & 400 \\
\hline Nuclear & 157 & 165 & $\mathrm{n} / \mathrm{a}$ & $\mathrm{n} / \mathrm{a}$ & 166 & 87 & 435 & 379 & 170 & 166 & 929 & 797 \\
\hline Oil & 0 & 0 & $\mathrm{n} / \mathrm{a}$ & $\mathrm{n} / \mathrm{a}$ & 0 & 0 & 1 & 0 & 0 & 0 & 1 & 1 \\
\hline Totals & 725 & 566 & $\mathbf{n} / \mathbf{a}$ & $\mathbf{n} / \mathbf{a}$ & 415 & 223 & 1,704 & 1,512 & 614 & 422 & 3,458 & 2,724 \\
\hline
\end{tabular}

${ }^{1}$ Water consumption was not modeled for once-through plants using saline water sources.

${ }^{2}$ Four combined-cycle plants that use oil as a fuel source are included in the NGCC category for recirculating towers in 2015. 


\section{Model-Estimated Thermoelectric Water Use in 2010 and 2015}

Model-estimated withdrawals decreased approximately $26 \mathrm{Bgal} / \mathrm{d}$, or 20 percent, since 2010 , from $129 \mathrm{Bgal} / \mathrm{d}$ to $103 \mathrm{Bgal} / \mathrm{d}$ (table 4). Withdrawals declined for all coolingsystem technology type categories (fig. 2; table 4). The largest decrease in total withdrawals occurred at plants with freshwater, once-through cooling systems (23-percent decrease), with the largest decline attributed to coal-fired plants in this category (16.8-Bgal/d decrease). Similarly, total withdrawals declined $6.9 \mathrm{Bgal} / \mathrm{d}$ at plants with complex cooling systems, with 83 percent of the decline attributed to coal-fired plants in that category (5.7-Bgal/d decrease). Since 2010, 36 plants with freshwater, once-through cooling systems and 12 complex-cooled plants were retired; 34 of these 48 were coal-fired plants. During the same 5 -year time period, no new plants with freshwater, once-through cooling systems came online, and only three complex-cooled plants became operational. Notably, total withdrawals increased for NGCC plants for all cooling-system types except for those with complex cooling systems. Of the 1,055 plants that were modeled in both 2010 and 2015, 69 percent had declines in withdrawal on the average of 40 percent.

Model-estimated consumption decreased approximately $734 \mathrm{Mgal} / \mathrm{d}$, or 21 percent, since 2010, from $3.5 \mathrm{Bgal} / \mathrm{d}$ to 2.7 Bgal/d (table 5). Consumption declined for all coolingsystem technology type categories (fig. 3; table 5). Although total consumption was the largest for plants with recirculating towers in 2010 and 2015, consumption rates decreased 11 percent for the category. Coinciding with the category's total withdrawals, total consumption increased for NGCC plants in all cooling-system type categories except for complex cooling systems. More than half of the plants that became operational during the 5-year period are NGCC plants, and all but one have recirculating cooling systems. Water consumption declined at 63 percent of the plants modeled in 2010 and 2015, with average declines of 39 percent.

Net electricity generation decreased approximately $243,000 \mathrm{GWh}$, or 7 percent, since 2010, from 3,457,000 GWh to $3,214,000 \mathrm{GWh}$ (table 3). Unlike withdrawal and consumption, net generation did not decline for all coolingsystem technology type categories (fig. 4; table 3). In fact, total net generation increased 9 percent for plants with recirculating cooling towers, most notably at NGCC plants with towers (54-percent increase). Mirroring the increases in withdrawals and consumption, total NGCC net generation increased for all cooling-system types except those with complex cooling systems. Conversely, total net generation declined for most of the generation and cooling-system technology type categories. Although they generated the greatest shares of electricity in 2010 and 2015, coal-fired plants decreased electricity output across all cooling-system types during that period, with a 28 -percent decline $(485,419$ GWh). Net generation at coal-fired plants with freshwater once-through cooling decreased 34 percent, or 190,747 GWh, between 2010 and 2015, which was the largest decrease in net generation of any generation or cooling-system technology type. Of the plants modeled in both years, 60 percent experienced declines in net generation, with an average decline of 35 percent. Thermoelectric power plants' share of total electricity generated by utility-scale power producers in the United States decreased 5 percent between 2010 and 2015, whereas photovoltaic-solar, wind, and combustion-gas plants increased their share of total combined U.S. electricity output by 3 percent during the same timeframe (U.S. Energy Information Administration, 2011, 2016d).

There were 234 plants that were modeled in 2010, but not modeled in 2015. Geothermal ( 35 plants) and solar thermal (13 plants) were removed from the modeling list for 2015, all of which had recirculating cooling systems. According to the EIA, 114 plants retired all water-using generators between 2010 and 2015. Of these retired plants, 63 plants had oncethrough or complex cooling systems, and 51 had recirculating towers or ponds (U.S. Energy Information Administration, $2016 \mathrm{c}$, d). The retired plants withdrew $6.2 \mathrm{Bgal} / \mathrm{d}$, consumed $84 \mathrm{Mgal} / \mathrm{d}$, and generated $88,585 \mathrm{GWh}$ in 2010 . Seventy-two plants were operational in 2015 but were not modeled for various reasons; they reported zero or negative net generation, were out of service for 2015, were classified as commercial or industrial facilities, or were changed to cooling-system or generation types that did not use water.

There were 1,055 plants that were modeled in both 2010 and 2015. For 2015, the generation technology type changed for 193 plants, and the cooling-system technology type changed for 39 plants. Additionally, 104 biomass plants were miscategorized as complex/multifuel plants in 2010, rather than grouping them in their own generation technology type category. 


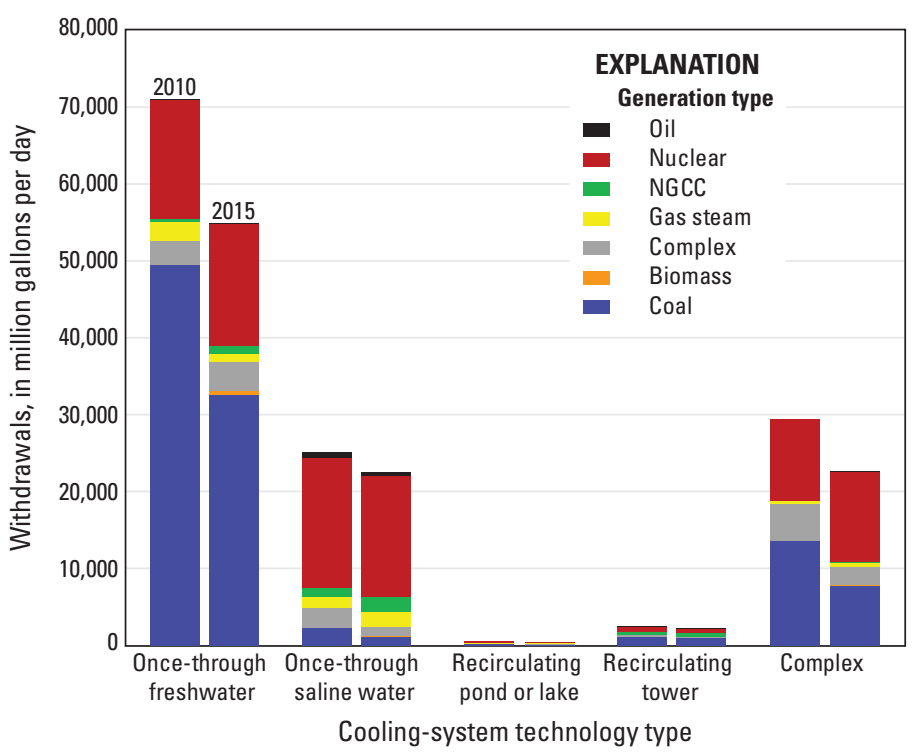

Figure 2. Model-estimated withdrawals by cooling-system and generation technology type for thermoelectric power plants in the United States, 2010 and 2015. [Estimates for 2010 are based on 1,242 plants. Estimates for 2015 are based on 1,122 plants. NGCC, natural gas combined cycle]

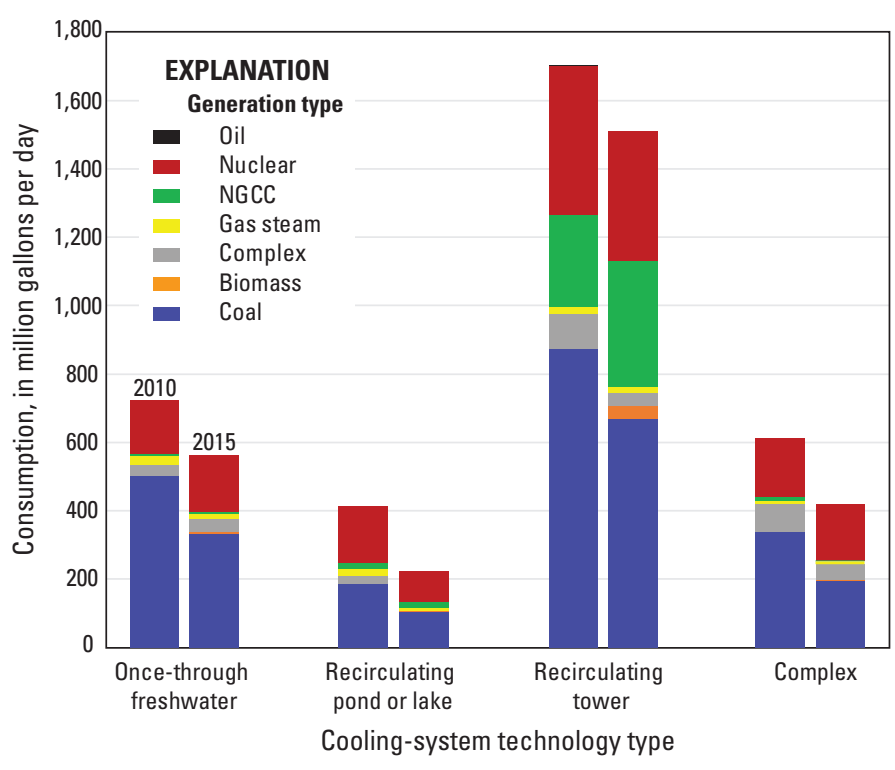

Figure 3. Model-estimated consumption by cooling-system and generation technology type for thermoelectric power plants in the United States, 2010 and 2015. [Estimates for 2010 are based on 1,156 plants. Estimates for 2015 are based on 1,052 plants. NGCC, natural gas combined cycle]

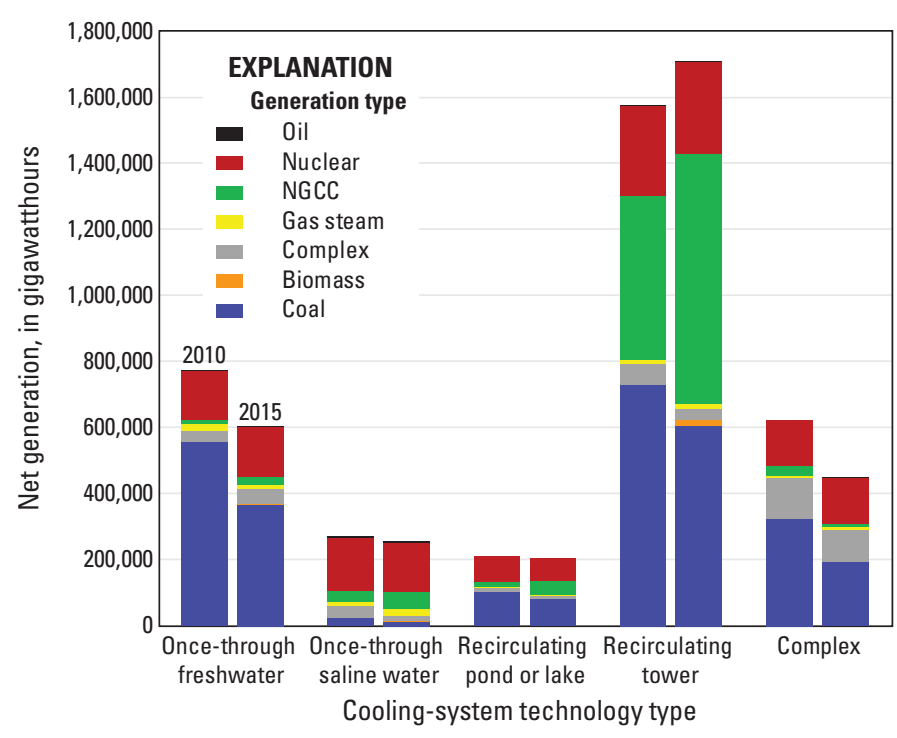

Figure 4. Net electric generation by cooling-system and generation technology type for thermoelectric power plants in the United States, 2010 and 2015. [Data for 2010 are based on 1,242 plants. Data for 2015 are based on 1,122 plants. Net electric generation data are from U.S. Energy Information Administration (2011, 2016d). NGCC, natural gas combined cycle] 


\section{Consumption and Withdrawal Coefficients}

Withdrawal and consumption coefficients were calculated only for the simple plants (tables 6 and 7). Though not derived from the full set of plants, these coefficients should be reasonably representative of water-use rates associated with given types of generation and cooling. Categorical coefficients for the simple plants appear more consistent by cooling type than for generation technology type.

Between the two years, once-through freshwater withdrawal and consumption coefficients changed little except for the small categories of gas steam and oil steam (tables 6 and 7). Once-through saline withdrawal coefficients showed no consistent trend (table 6); the withdrawal coefficients for oil and gas steam decreased, coal increased, and NGCC and nuclear remained the same for the two years of analysis.
Recirculating pond and recirculating tower withdrawal and consumption coefficients decreased for all generation technology types.

Censoring the data to 430 plants selected for comparability had small, inconsistent effects on coefficients (tables 8 and 9). The decrease in coefficients for oncethrough freshwater gas steam (tables 6 and 7) was reversed (tables 8 and 9); removal of gas steam recirculating pond outliers eliminated the large decrease in coefficients for this category. Despite being selected for comparability, some of these 430 plants exhibited large changes in their consumption coefficient; outliers may be the result of data or definitional issues (figs. 5 and 6). Based on modeled values, withdrawal (fig. 7) and consumption (fig. 6) coefficients can change by 10 percent or more at individual plants without documented changes in equipment or operations.

Table 6. Withdrawal coefficients by generation and cooling-system technology types for thermoelectric power plants in the United States, 2010 and 2015.

[All values are in gallons per kilowatthour. Coefficients for 2010 are based on 889 plants. Coefficients for 2015 are based on 958 plants. NGCC, natural gas combined cycle; $\mathrm{n} / \mathrm{a}$, not applicable]

\begin{tabular}{|c|c|c|c|c|c|c|c|c|}
\hline \multirow{2}{*}{$\begin{array}{c}\text { Generation } \\
\text { technology } \\
\text { type }\end{array}$} & \multicolumn{8}{|c|}{ Cooling-system technology type } \\
\hline & \multicolumn{2}{|c|}{$\begin{array}{l}\text { Once-through } \\
\text { freshwater }\end{array}$} & \multicolumn{2}{|c|}{$\begin{array}{l}\text { Once-through } \\
\text { saline water }\end{array}$} & \multicolumn{2}{|c|}{$\begin{array}{l}\text { Recirculating } \\
\text { pond or lake }\end{array}$} & \multicolumn{2}{|c|}{$\begin{array}{l}\text { Recirculating } \\
\text { tower }\end{array}$} \\
\hline Biomass & $\mathrm{n} / \mathrm{a}$ & 65 & $\mathrm{n} / \mathrm{a}$ & 64 & $\mathrm{n} / \mathrm{a}$ & 0.68 & $\mathrm{n} / \mathrm{a}$ & 0.98 \\
\hline Coal & 32 & 32 & 32 & 35 & 0.65 & 0.49 & 0.64 & 0.57 \\
\hline Nuclear & 39 & 39 & 39 & 39 & 0.78 & 0.48 & 0.81 & 0.70 \\
\hline Oil & 56 & 39 & 47 & 36 & $\mathrm{n} / \mathrm{a}$ & $\mathrm{n} / \mathrm{a}$ & 0.99 & 0.95 \\
\hline
\end{tabular}

*Four combined-cycle plants that use oil as a fuel source are included in the NGCC category for recirculating towers in 2015.

Table 7. Consumption coefficients by generation and cooling-system technology types for thermoelectric power plants in the United States, 2010 and 2015.

[All values are in gallons per kilowatthour. Coefficients for 2010 are based on 824 plants. Coefficients for 2015 are based on 900 plants. NGCC, natural gas combined cycle; $\mathrm{n} / \mathrm{a}$, not applicable]

\begin{tabular}{|c|c|c|c|c|c|c|c|c|}
\hline \multirow{2}{*}{$\begin{array}{c}\text { Generation } \\
\text { technology } \\
\text { type }\end{array}$} & \multicolumn{8}{|c|}{ Cooling-system technology type } \\
\hline & \multicolumn{2}{|c|}{$\begin{array}{l}\text { Once-through } \\
\text { freshwater }\end{array}$} & \multicolumn{2}{|c|}{$\begin{array}{l}\text { Once-through } \\
\text { saline water }\end{array}$} & \multicolumn{2}{|c|}{$\begin{array}{l}\text { Recirculating } \\
\text { pond or lake }\end{array}$} & \multicolumn{2}{|c|}{$\begin{array}{c}\text { Recirculating } \\
\text { tower }\end{array}$} \\
\hline Biomass & $\mathrm{n} / \mathrm{a}$ & 0.63 & $\mathrm{n} / \mathrm{a}$ & $\mathrm{n} / \mathrm{a}$ & $\mathrm{n} / \mathrm{a}$ & 0.68 & $\mathrm{n} / \mathrm{a}$ & 0.70 \\
\hline Coal & 0.33 & 0.33 & $\mathrm{n} / \mathrm{a}$ & $\mathrm{n} / \mathrm{a}$ & 0.65 & 0.49 & 0.44 & 0.40 \\
\hline Nuclear & 0.40 & 0.40 & $\mathrm{n} / \mathrm{a}$ & $\mathrm{n} / \mathrm{a}$ & 0.78 & 0.48 & 0.58 & 0.50 \\
\hline Oil & 0.59 & 0.35 & $\mathrm{n} / \mathrm{a}$ & $\mathrm{n} / \mathrm{a}$ & $\mathrm{n} / \mathrm{a}$ & $\mathrm{n} / \mathrm{a}$ & 0.70 & 0.68 \\
\hline
\end{tabular}

${ }^{1}$ Water consumption was not modeled for once-through plants using saline water sources.

${ }^{2}$ Four combined-cycle plants that use oil as a fuel source are included in the NGCC category for recirculating towers in 2015. 
Table 8. Average withdrawal coefficients by generation and cooling-system technology types for 430 thermoelectric power plants in the United States, 2010 and 2015.

[All values are in gallons per kilowatthour. NGCC, natural gas combined cycle; n/a, not applicable]

\begin{tabular}{|c|c|c|c|c|c|c|c|c|}
\hline \multirow{3}{*}{$\begin{array}{c}\text { Generation } \\
\text { technology } \\
\text { type }\end{array}$} & \multicolumn{8}{|c|}{ Cooling-system technology type } \\
\hline & \multicolumn{2}{|c|}{$\begin{array}{l}\text { Once-through } \\
\text { freshwater }\end{array}$} & \multicolumn{2}{|c|}{$\begin{array}{l}\text { Once-through } \\
\text { saline water }\end{array}$} & \multicolumn{2}{|c|}{$\begin{array}{l}\text { Recirculating } \\
\text { pond or lake }\end{array}$} & \multicolumn{2}{|c|}{$\begin{array}{l}\text { Recirculating } \\
\text { tower }\end{array}$} \\
\hline & 2010 & 2015 & 2010 & 2015 & 2010 & 2015 & 2010 & 2015 \\
\hline Coal & 32 & 33 & 32 & 35 & 0.63 & 0.48 & 0.63 & 0.5 \\
\hline Gas steam & 40 & 43 & 37 & 36 & 2.44 & 2.27 & 0.79 & 0.6 \\
\hline $\mathrm{NGCC}^{*}$ & 16 & 16 & 15 & 15 & 0.30 & 0.16 & 0.29 & 0.2 \\
\hline Nuclear & 39 & 39 & 39 & 39 & 0.72 & 0.48 & 0.81 & 0.7 \\
\hline Oil & $\mathrm{n} / \mathrm{a}$ & $\mathrm{n} / \mathrm{a}$ & 47 & 36 & $\mathrm{n} / \mathrm{a}$ & $\mathrm{n} / \mathrm{a}$ & 1.02 & 0.9 \\
\hline
\end{tabular}

${ }^{*}$ Four combined-cycle plants that use oil as a fuel source are included in the NGCC category for recirculating towers in 2015.

Table 9. Average consumption coefficients by generation and cooling-system technology types for 430 thermoelectric power plants in the United States, 2010 and 2015.

[All values are in gallons per kilowatthour. NGCC, natural gas combined cycle; n/a, not applicable]

\begin{tabular}{|c|c|c|c|c|c|c|c|c|}
\hline \multirow{2}{*}{$\begin{array}{c}\text { Generation } \\
\text { technology } \\
\text { type }\end{array}$} & \multicolumn{8}{|c|}{ Cooling-system technology type } \\
\hline & \multicolumn{2}{|c|}{$\begin{array}{l}\text { Once-through } \\
\text { freshwater }\end{array}$} & \multicolumn{2}{|c|}{$\begin{array}{l}\text { Once-through } \\
\text { saline water }\end{array}$} & \multicolumn{2}{|c|}{$\begin{array}{l}\text { Recirculating } \\
\text { pond or lake }\end{array}$} & \multicolumn{2}{|c|}{$\begin{array}{c}\text { Recirculating } \\
\text { tower }\end{array}$} \\
\hline Coal & 0.32 & 0.34 & $\mathrm{n} / \mathrm{a}$ & $\mathrm{n} / \mathrm{a}$ & 0.63 & 0.48 & 0.44 & 0.40 \\
\hline Gas steam & 0.46 & 0.49 & $\mathrm{n} / \mathrm{a}$ & $\mathrm{n} / \mathrm{a}$ & 2.44 & 2.27 & 0.56 & 0.47 \\
\hline Oil & $\mathrm{n} / \mathrm{a}$ & $\mathrm{n} / \mathrm{a}$ & $\mathrm{n} / \mathrm{a}$ & $\mathrm{n} / \mathrm{a}$ & $\mathrm{n} / \mathrm{a}$ & $\mathrm{n} / \mathrm{a}$ & 0.73 & 0.68 \\
\hline
\end{tabular}

${ }^{1}$ Water consumption was not modeled for once-through plants using saline water sources.

${ }^{2}$ Four combined-cycle plants that use oil as a fuel source are included in the NGCC category for recirculating towers in 2015.

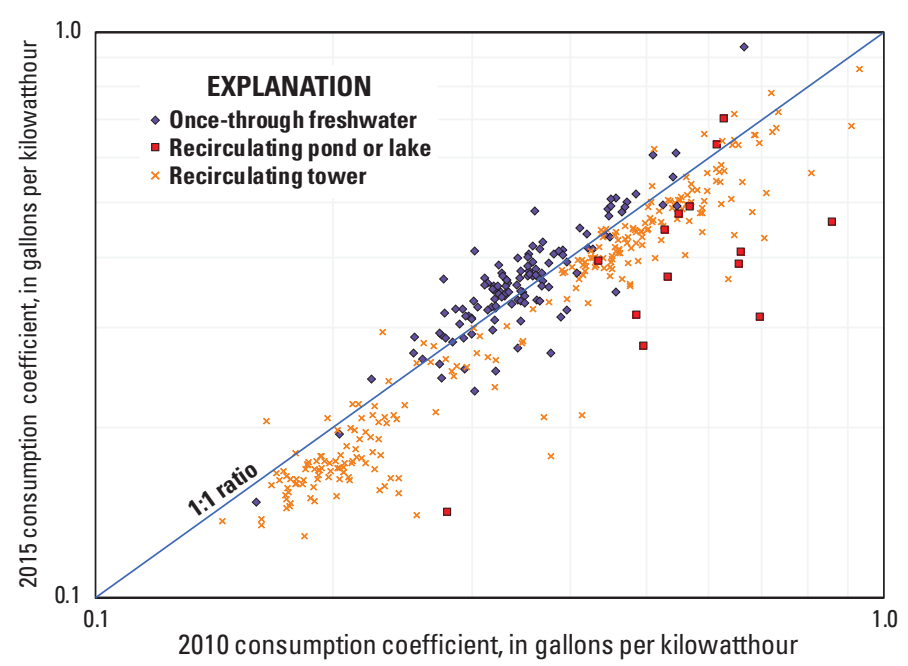

Figure 5. Consumption coefficients less than 1 gallon per kilowatthour by cooling-system technology type for 430 thermoelectric power plants in the United States, 2010 and 2015.

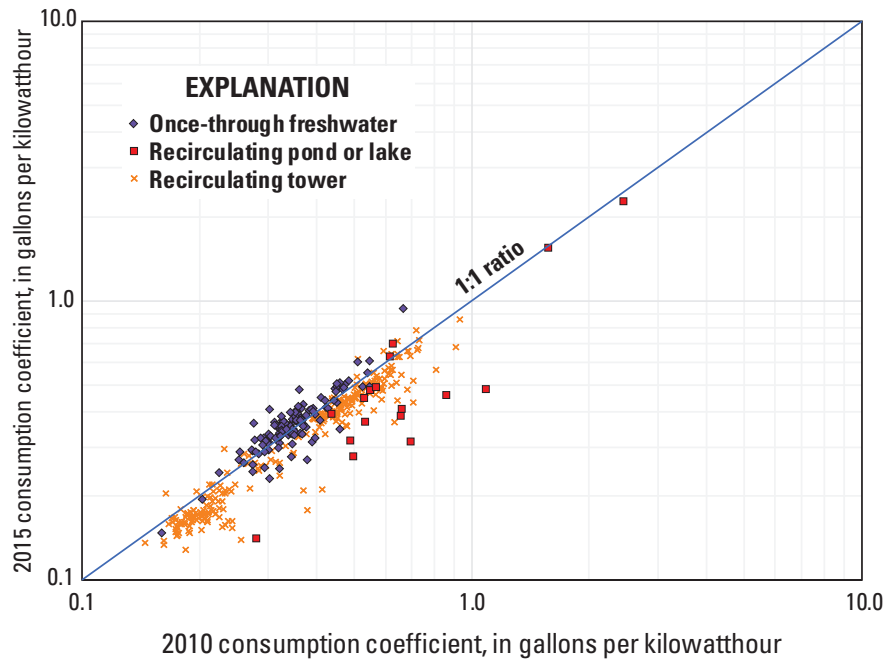

Figure 6. Consumption coefficients by cooling-system technology type for 430 thermoelectric power plants in the United States, 2010 and 2015. 




Figure 7. Withdrawal coefficients by cooling-system type for 430 thermoelectric power plants in the United States, 2010 and 2015.

\section{Conclusions}

The analyses presented in this report lead to the following conclusions.

- Total model-estimated withdrawal for 2015 was $103 \mathrm{Bgal} / \mathrm{d}$, a 20-percent decline from 2010.

- Total model-estimated consumption for 2015 was 2.7 Bgal/d, a 21-percent decline from 2010.

- Total thermoelectric utility-scale electricity production decreased 7 percent between 2010 and 2015; the share of total electricity generated by utility-scale power producers in the United States declined 5 percent.

- Declines in withdrawals were mostly due to decreased electricity production at, and closure of, coal-fired power plants with once-through cooling.

- Although withdrawal and consumption increased for the NGCC generation technology type category between 2010 and 2015, declines in total withdrawals and consumption were due in part to more electricity being generated by NGCC plants, which are more energy- and water-efficient than other types of thermoelectric plants.

\section{References}

Arias, M.A., Reinbold, B., Restrepo-Echavarria, P., 2017, The decline of coal: Federal Reserve Bank of St. Louis, Economic Synopses, no. 16, accessed September 13, 2018, at https://doi.org/10.20955/es.2017.16.

Astolfi, M., Romano, M.C., Bombarda, P., and Macchi, E., 2014, Binary ORC (organic Rankine cycles) power plants for the exploitation of medium-low temperature geothermal sources-Part A: Thermodynamic optimization: Energy, v. 66, p. 423-434, accessed July 18, 2019, at https://www.sciencedirect.com/science/article/abs/pii/ S0360544213010268.

Averyt, K., Macknick, J., Rogers, J., Madden, N., Fisher, J., Meldrum, J., and Newmark, R., 2013, Water use for electricity in the United States: An analysis of reported and calculated water use information for 2008: Environmental Research Letters, v. 8, no. 1, p. 1-9, accessed July 10, 2015, at https://doi.org/10.1088/1748-9326/8/1/015001.

Bracken, N., Macknick, J., Tovar-Hastings, A., Komor, P., Gerritsen, M., and Mehta, S., 2015, Concentrating solar power and water issues in the U.S. Southwest: Joint Institute for Strategic Energy Analysis, 89 p., accessed July 18, 2019, at https://www.nrel.gov/docs/fy15osti/61376.pdf.

Carter, N.T., and Campbell, R.J., 2009, Water issues of concentrating solar power (CSP) electricity in the U.S. Southwest: Congressional Research Service, Library of Congress, accessed July 18, 2019, at https://www. circleofblue.org/wp-content/uploads/2010/08/Solar-WaterUse-Issues-in-Southwest.pdf.

Clement, Z., Fields, F., Bauer, D., Tidwell, V., Shaneyfelt, C.R., and Klise, G., 2017, Effects of cooling system operations on withdrawal for thermoelectric power, in ASME 2017 Power Conference Joint with ICOPE17 collocated with the ASME 2017 11th International Conference on Energy Sustainability, the ASME 2017 15th International Conference on Fuel Cell Science, Engineering and Technology, and the ASME 2017 Nuclear Forum: American Society of Mechanical Engineers, p. V001T03A001-V001T03A007. 
Damerau, K., Williges, K., Patt, A.G., and Gauché, P., 2011, Costs of reducing water use of concentrating solar power to sustainable levels - Scenarios for North Africa: Energy Policy, v. 39, no. 7, p. 4391-4398, accessed July 18, 2019, at https://www.sciencedirect.com/science/article/pii/ S0301421511003429.

Diehl, T.H., and Harris, M.A., 2014, Withdrawal and consumption of water by thermoelectric power plants in the United States, 2010: U.S. Geological Survey Scientific Investigations Report 2014-5184, 28 p., accessed July 18, 2019, at http://dx.doi.org/10.3133/sir20145184.

Diehl, T.H., Harris, M.A., Murphy, J.C., Hutson, S.S., and Ladd, D.E., 2013, Methods for estimating water consumption for thermoelectric power plants in the United States: U.S. Geological Survey Scientific Investigations Report 2013-5188, 78 p., accessed July 18, 2019, at http:// dx.doi.org/10.3133/sir20135188.

Dieter, C.A., Maupin, M.A., Caldwell, R.R., Harris, M.A., Ivahnenko, T.I., Lovelace, J.K., Barber, N.L., and Linsey, K.S., 2018, Estimated use of water in the United States in 2015: U.S. Geological Survey Circular 1441, 65 p., accessed July 18, 2019, at https://doi.org/10.3133/cir1441.

Electric Power Research Institute, 2012, Economic evaluation of alternative cooling technologies: Palo Alto, Calif., Electric Power Research Institute product ID 1024805, accessed July 18, 2019, at https:/www.epri.com/\#/pages/ product/1024805/?lang=en.

Harris, M.A., and Diehl, T.H., 2017, A comparison of three federal datasets for thermoelectric water withdrawals in the United States for 2010: Journal of the American Water Resources Association, v. 53, no. 5, p. 1062-1080, accessed July 18, 2019, at https://doi.org/10.1111/1752-1688.12551.

Harris, M.A., and Diehl, T.H., 2019, Water withdrawal and consumption estimates for thermoelectric power plants in the United States, 2015: U.S. Geological Survey data release, https://doi.org/10.5066/P9V0T04B.

Kolstad, C.D., 2017, What is killing the U.S. coal industry?: Stanford Institute for Economic Policy Research, Policy Brief, accessed September 14, 2018, at https://siepr. stanford.edu/research/publications/what-killing-us-coalindustry.

Krivoruchko, Konstantin, 2012, Empirical Bayesian kriging: ArcUser, v. 15, no. 4, p. 6-10.
Lee, U., Han, J., Elgowainy, A., and Wang, M., 2018, Regional water consumption for hydro and thermal electricity generation in the United States: Applied Energy, v. 210, p. 661-672, accessed October 19, 2017, at https://doi. org/10.1016/j.apenergy.2017.05.025.

Macknick, J., Newmark, R., Heath, G., and Hallett, K.C., 2011, A review of operational water consumption and withdrawal factors for electricity generating technologies: National Renewable Energy Laboratory Technical Report NREL/TP-6A20-50900, 21 p., accessed October 18, 2018, at http://www.nrel.gov/docs/fy11osti/50900.pdf.

Maupin, M.A., Kenny, J.F., Hutson, S.S., Lovelace, J.K., Barber, N.L., and Linsey, K.S., 2014, Estimated use of water in the United States in 2010: U.S. Geological Survey Circular 1405, 56 p., accessed October 3, 2017, at https:// doi.org/10.3133/cir1405.

Meldrum, J., Nettles-Anderson, S., Heath, G., and Macknick, J., 2013, Life cycle water use for electricity generation-A review and harmonization of literature estimates: Environmental Research Letters, v. 8, no. 1, 18 p., accessed October 4, 2018, at https://doi.org/10.1088/17489326/8/1/015031.

National Oceanic and Atmospheric Administration, 2015, Great Lakes Surface Environmental Analysis (GLSEA2): NOAA Great Lakes Environmental Research Laboratory, Ann Arbor, MI, accessed July 18, 2019, at https:// coastwatch.glerl.noaa.gov/glsea/doc/.

Peer, R.A.M., and Sanders, K.T., 2016, Characterizing cooling water source and usage patterns across US thermoelectric power plants - A comprehensive assessment of selfreported cooling water data: Environmental Research Letters, v. 11, no. 12, p. 1-10, accessed October 19, 2017, at https://doi.org/10.1088/1748-9326/aa51d8.

Pilz, J., and Spöck, G., 2007, Why do we need and how should we implement Bayesian kriging methods: Stochastic Environmental Research and Risk Assessment, v. 22, no. 5, p. $621-632$.

R Development Core Team, 2017, R: A language and environment for statistical computing: Vienna, Austria, R Foundation for Statistical Computing, accessed July 18, 2019, at http://www.R-project.org/.

Rao, A.D., ed., 2012, Combined cycle systems for near-zero emission power generation: Sawston, United Kingdom, Woodhead Publishing, 360 p. 
Stiegel, G.J., Longanbach, J.R., Rutkowski, M.D., Klett, M.G., Kuehn, N.J., Schoff, R.L., Vaysman, V., and White, J.S., 2005, Power plant water usage and loss study: U.S. Energy Information Administration, National Energy Technology Laboratory technical report.

Storm, R.F., 2018, The most efficient thermal power generation plants in America: Williamson College of the Trades, accessed August 2, 2019, at https://www. williamson.edu/2018/05/the-most-efficient-thermal-powergeneration-plants-in-america/.

Taylor, L., Water, M., and Krumdieck, S., 2013, Development of a low temperature geothermal organic rankine cycle standard, in New Zealand Geothermal Workshop, Rotorua, New Zealand, November 17-20, 2013, Proceedings, accessed December 1, 2018, at http://hdl.handle. net/10092/10240.

Tchanche, B.F., 2016, Geothermal energy and organic rankine cycle machines, in Lehr, J.H., Keeley, J., and Kingery, T.B., eds., Alternative energy and shale gas encyclopedia: John Wiley \& Sons, Inc., p. 310-317, accessed December 1, 2018, at https://onlinelibrary.wiley.com/doi/ abs/10.1002/9781119066354.ch30.

U.S. Energy Information Administration, 2011, 2010 Form EIA-923 database: U.S. Energy Information Administration, Power Plant Operations Report, accessed January 2018 at http://www.eia.gov/electricity/data/eia923/.

U.S. Energy Information Administration, 2016a, Annual energy outlook 2016 with projections to 2040: U.S. Energy Information Administration, Office of Energy Analysis, DOE/EIA-0383(2016), 256 p.
U.S. Energy Information Administration, 2016b, Trends in U.S. oil and natural gas upstream costs: Washington, D.C., U.S. Energy Information Administration, 141 p.

U.S. Energy Information Administration, 2016c, 2015 Form EIA-860 database: U.S. Energy Information Administration, Annual Electric Generator Report, accessed January 2018 at http://www.eia.gov/electricity/data/eia860/index.html.

U.S. Energy Information Administration, 2016d, 2015 Form EIA-923 database: U.S. Energy Information Administration, Power Plant Operations Report, accessed January 2018 at http://www.eia.gov/electricity/data/eia923/.

U.S. Energy Information Administration, 2018, Almost all power plants that retired in the past decade were powered by fossil fuels: Today in Energy, accessed June 21, 2018, at https://www.eia.gov/todayinenergy/detail.php?id=34452.

U.S. Environmental Protection Agency, 2014, Clean Water Act, section 316(b), National Pollutant Discharge Elimination System-Final regulations to establish requirements for cooling water intake structures at existing facilities and amend requirements at phase I facilities: 40 CFR Parts 122 \& 125 (document number 2014-12164).

U.S. Geological Survey, 2017, USGS water data for the Nation: U.S. Geological Survey National Water Information System database, accessed April 10, 2017, at https://doi. org/10.5066/F7P55KJN.

Zarrouk, S.J., and Moon, H., 2014, Efficiency of geothermal power plants - A worldwide review: Geothermics, v. 51, p. 142-153, accessed December 1, 2018, at https://www. sciencedirect.com/science/article/pii/S0375650513001120. 
For more information, contact U.S. Geological Survey National Water Use Science Project Team

wu-info@usgs.gov

or visit our website at https://water.usgs.gov/watuse/

Publishing support provided by Lafayette Publishing Service Center 



\section{$\frac{\mathbb{2}}{3}$}

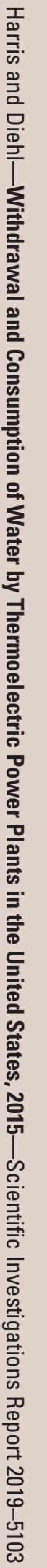

